\title{
Research on the Connotation of Rural Tourism in the New Era of China
}

\author{
Zibiao Cheng \\ Financial and Management Institute, Sichuan University of Arts and Science, Dazhou, China \\ Email: 280302327@qq.com
}

How to cite this paper: Cheng, Z.B. (2019) Research on the Connotation of Rural Tourism in the New Era of China. Open Journal of Social Sciences, 7, 358-365. https://doi.org/10.4236/jss.2019.710030

Received: October 17, 2019

Accepted: October 25, 2019

Published: October 28, 2019

Copyright $\odot 2019$ by author(s) and Scientific Research Publishing Inc. This work is licensed under the Creative Commons Attribution International License (CC BY 4.0).

http://creativecommons.org/licenses/by/4.0/

\begin{abstract}
This paper selects 15 rural tourism concepts for comparative study, and finds that the concept of rural tourism evolves with the development of the times. Based on the analysis of the characteristics of the new era, the concept of rural tourism in the new era is put forward. Finally, the connotation of rural tourism in the era is analyzed. It is believed that rural tourism in the new era has connotations of peasant-led, source-protecting quality of planning and developing, rural cultural self-confidence, coordination and sharing, etc.
\end{abstract}

\section{Keywords}

China, New Age, Rural Tourism, Connotation

\section{Introduction}

On October 18, 2017, General Secretary Xi Jinping, on behalf of the eighteen central committees, delivered a report to the Congress entitled "a decisive victory in building the Xiaokang in all respects and striving for the great victory of socialism with Chinese characteristics for a new era", "after a long period of hard work, socialism with Chinese characteristics has entered a new era, which is a new historical orientation for China's development", he said "the connotation of rural tourism has been enriched and its charm has been enhanced". In order to promote the development of rural tourism in the new era, it is necessary to analyze the connotation of rural tourism based on the characteristics of the times and the full understanding of national policies.

\section{Definition of Rural Tourism by Domestic Scholars}

The 15 rural tourism concepts were selected for comparative analysis, and the selection principles followed the following three aspects. First, the concept has 
been cited many times with high recognition. Secondly, the author has certain authority in the research of rural tourism. Thirdly, the concepts proposed at different times are selected to ensure that the time defined by the different concepts has a certain span, so as to analyze the evolvement rule of the rural tourism concept with the development of the times.

According to Table 1, the research and analysis of rural tourism concepts conducted by experts and scholars from different research backgrounds in different periods have obtained the following analysis results. First, the concepts of rural tourism have common points, and it is believed that rural tourism occurs in rural areas. Second, the concept of rural tourism has its own focus. For example, Yang Xu (1992), Yao Suying (1997), Ma Bo (1996), Du Jiang (1999), He Jingming (2002), Cha Fang (2004), Liu Hongyan (2005), and Li Kaiyu (2005) these scholars focused on defining the concept of rural tourism from the perspective of tourism resources, that is, tourism attractions. While, scholars like Xiao Youxing (2001), Zhang Jie (2005), Lin Gang (2006) and Guo Li (2010) combined tourism resources and forms to define the concept of rural tourism. However, Liu Yingjie (2006) and Tao Yuxia (2009) defined the concept of rural tourism at different levels. Lu Xiaoli (2017) defined the concept of rural tourism from the aspects of tourism region, tourism resources, tourists and tourism purposes. Third, the development of the times has given new connotation to rural tourism, and the evolution of the concept of rural tourism is basically in step with the development of the times. In 2005, Zhang Jie (2005) pointed out that rural tourism should obtain economic and social benefits. In 2009, Tao Yuxia (2009) focused on the realization of human development and liberation. In 2017, $\mathrm{Lu}$ Xiaoli (2017) believed that rural tourism was a form of tourism and tourism activities oriented by sustainable tourism. Therefore, it can be seen that the concept of rural tourism has evolved from paying attention to benefits to human development to sustainable development, which basically coincides with the track of Chinese economy from high-speed growth to high-quality development. However, the concept of rural tourism is not synchronized with the five development concepts of innovation, coordination, green, openness and sharing in the new era, the structural reform on the supply side, and the strategy of economic transformation and upgrading. Therefore, it is urgent to comprehensively and thoroughly understand the connotation of the important judgment of socialism with Chinese characteristics in a new era, so as to accurately grasp the concept and connotation of rural tourism.

\section{Characteristics of the New Era}

Xi Jinping's report on the nineteenth National Congress of the Communist Party of China is divided into 13 parts, involving all aspects of the overall layout of the Five-sphere Integrated Plan. Therefore, the following five aspects of construction in the new era will be expounded: economic construction, political construction, cultural construction, social construction and ecological civilization construction. 
Table 1. A list of concepts of domestic rural tourism [1]-[14].

\begin{tabular}{|c|c|c|c|}
\hline Number & Author & Year & Concept \\
\hline 1 & Yang Xu & 1992 & $\begin{array}{l}\text { The three-dimensional landscape composed of agricultural biological resources, agricultural economic resources, } \\
\text { and rural social resources is the tourism activities. }\end{array}$ \\
\hline 2 & Yao Suying & 1997 & $\begin{array}{l}\text { It is a special way of tourism that enables tourists to appreciate the interest of nature and modern new countryside } \\
\text { that they hardly be seen in the city, which makes rational use of existing resources in rural areas and integrates } \\
\text { viewing, enjoying, travel, study, purchase, etc. through scientific planning, design and processing. }\end{array}$ \\
\hline 3 & Mao Bo & 1996 & $\begin{array}{l}\text { Rural tourism is a kind of activity place based on rural community, with unique production form, life style and } \\
\text { rural scenery. }\end{array}$ \\
\hline 4 & Du Jiang & 1999 & $\begin{array}{l}\text { Peasants provide tourists with accommodation and other conditions to engage in various leisure activities in } \\
\text { typical rural environments such as farms and pastures. }\end{array}$ \\
\hline 5 & Xiao Youxing & 2001 & $\begin{array}{l}\text { It is a form of tourism that integrates sightseeing, sightseeing, entertainment, leisure, vacation and shopping, } \\
\text { which based on the rural space environment, taking the unique rural production form, folk customs, lifestyle, } \\
\text { rural scenery, rural residence, and rural culture as the object, and using the differences between urban and rural to } \\
\text { plan and combine products, integrating sightseeing, tourism, entertainment, leisure, vacation and shopping. }\end{array}$ \\
\hline 6 & He Jingming & 2002 & It is a kind of tourism activity in rural areas with rural natural and human objects as tourism attractions. \\
\hline 7 & Cha Fang & 2004 & It is a tourist activity in rural areas with a rural landscape as a tourist attraction. \\
\hline 8 & Liu Hongyan & 2005 & $\begin{array}{l}\text { A form of eco-tourism takes rural communities as its activity sites, with rural natural ecological environment, } \\
\text { settlement economic, and cultural landscapes as tourism resources, and living environment, lifestyle, living } \\
\text { experience, and farming practices are different from local the rural communities where residents are the target } \\
\text { markets. }\end{array}$ \\
\hline 9 & Li Kaiyu & 2005 & $\begin{array}{l}\text { A tourism based on the development of rural tourism resources formed by tourists' perception of rural space and } \\
\text { rural imagery. }\end{array}$ \\
\hline 10 & Zhang Jie & 2005 & $\begin{array}{l}\text { It refers to a way of tourism in rural areas, with rural natural and cultural landscape as tourism attraction, urban } \\
\text { residents as the main target market, through meeting the leisure, knowledge and return to nature and other needs } \\
\text { of tourists to obtain economic and social benefits. }\end{array}$ \\
\hline 11 & Liu Yingjie & 2006 & $\begin{array}{l}\text { The concept system of rural tourism consists of subject module, object module and target module, which is closely } \\
\text { related to agricultural tourism and eco-tourism. }\end{array}$ \\
\hline 12 & Lin Gang & 2006 & $\begin{array}{l}\text { It is a kind of leisure, sightseeing, visiting and holiday activity that takes place in rural areas, and takes natural and } \\
\text { cultural landscapes as tourist attractions, such as rural pastoral customs, agricultural production activities, rural } \\
\text { life and folk culture. }\end{array}$ \\
\hline 13 & Tao Yuxia & 2009 & The core of the three-level concept of rural tourism is the realization of human development and liberation. \\
\hline 14 & Guo Li & 2010 & $\begin{array}{l}\text { In rural areas, with rural natural and cultural landscapes as attractions, tourists can enjoy rural countryside } \\
\text { scenery, experience agricultural production process, understand local customs, and return to nature. It is an } \\
\text { economical tourism activity that integrates viewing, investigation, learning, participation, entertainment, } \\
\text { shopping and vacation, which can meet the needs of tourists to seek differences, knowledge and origin. }\end{array}$ \\
\hline 15 & Lu Xiaoli & 2017 & $\begin{array}{l}\text { It is a form of tourism and tourism activities, aiming at leisure and learning, based on the rural environment, with } \\
\text { the rural material and intangible cultural heritage, natural landscape and agricultural activities as the core tourism } \\
\text { resources, with urban residents as the main source market and sustainable tourism as the development } \\
\text { orientation. }\end{array}$ \\
\hline
\end{tabular}

\subsection{Improving the Quality and Efficiency of Economic Development}

In the past 70 years, China's economy has developed rapidly, but in the new era, we will no longer blindly pursue the rapid economic development. Under the guidance of the five development concepts, we will promote supply side structural reform, accelerate the adjustment and upgrading of industrial structure, and pay more attention to the quality of economic development while improving the efficiency of economic development. 


\subsection{Strong and Powerful Political Construction}

In the new era, under the guidance of Marxism Leninism, Mao Zedong thought, Deng Xiaoping theory, the important thought of Three Represents theory and the scientific development, and in combination with the characteristics of the new era, the Communist Party of China will creatively deepen its understanding of the Communist Party, the socialist construction and the human social development, and form a theoretical system of political construction in the new era. It is also needed to unify the thoughts and actions of the whole party, keep in mind the original intention and mission of the Chinese Communists, and unswervingly follow the path of socialism with Chinese characteristics.

\subsection{Increasing Cultural Confidence}

General Secretary Xi Jinping put forward four self-confidences at the celebration of the 95th anniversary of the founding of the Communist Party of China, that is, self-confidence of socialism socialist road with Chinese characteristics, theoretical self-confidence, institutional self-confidence, and cultural self-confidence, and cultural self-confidence is the root and the soul. China is one of the four ancient civilizations. In five thousand years of history, 56 compatriots of all ethnic groups have accumulated profound historical and cultural deposits. Although the Chinese traditional culture has been impacted by the foreign culture to some extent in the process of inheritance and development since its reform and opening up, it is believe that the cultural confidence will continue to emerge with the support of profound Chinese excellent history and culture, through the activities of remembering nostalgia, One Belt and One Road initiative, world peace, and the community of human destiny, so as to continuously promote the innovation and inheritance of Chinese excellent rural culture, to boom the rural culture.

\subsection{Coordinated Sharing of Social Development}

In the new era, China has regarded the imbalance and inadequacy of development as the main contradiction of society. It will pay more attention to people and nature, people and society, people and people, and promote the coordination and sharing of social development. In terms of human and nature, under the guidance of the new development concept, the phenomenon of excessive demand for natural resources will be gradually eliminated by promoting industrial transformation and upgrading, and attach importance to the protection of the natural environment, so as to promote the dynamic balance between economic development and the natural environment. In terms of people and society, continuously promote supply side structural reform to retard the contradictions between people's demand and social supply is needed. And the problem of treatment, education, and pension will no longer be the biggest problem for citizens. Between people, with the implementation of a series of policy documents, such as Opinions of the Central Committee of the Communist Party of China and the State Council on the implementation of the strategy of Rural Revitaliza- 
tion, Revitalization and Development Plan of Sichuan and Shaanxi Old Revolutionary Base Area, Opinions of the Central Committee of the Communist Party of China and the State Council on Establishing a More Effective New Mechanism for Regional Coordinated Development, it will further promote the city drives rural development, promote coordinated regional development, and narrow the gap between urban and rural areas in infrastructure and public services.

\subsection{Balance and Beauty of Ecological Environment}

Under the guidance of the important statements, such as life community of mountains, rivers, forests, fields and lakes, and lucid waters and lush mountains are invaluable assets, China has issued a series of documents: Outline of the 13th Five Fear Plan for National Ecological Protection, National Ecotourism Development Plan in 2016-2025, and so on. They put the ecological environment protection in a prominent position, to promote the implementation of strategies such as the construction of beautiful villages, and formed the idea that the people protect the ecological environment as they protect their eyes, and treat the ecological environment as they treat their lives. In the new era, the ecological environment will generally maintain a dynamic balance, showing the beauty of the China in different regions.

\section{The Connotation of Rural Tourism in the New Era}

According to the analysis of the concept of rural tourism made by experts and scholars of different research backgrounds in different periods, and combined with the characteristics of the new era, the author believes that rural tourism in the new era is a high-quality sustainable tourism with peasants as the main body of operation, rural beautiful natural environment as the basis, and excellent rural culture as the soul.

The correct understanding and excavation of the connotation of rural tourism can make clear of the main body, form, purpose, direction and orientation of the development of rural tourism, so as to make a scientific and reasonable development plan, maintain high-quality and sustainable development, and ensure the synchronous development of rural tourism and the new era. The author thinks that rural tourism in the new era has such connotations: peasant-led, source-protecting quality of planning and developing, rural cultural self-confidence, coordination and sharing, etc.

\subsection{Peasant-Led}

When scholars define the concept of rural tourism, they emphasize that the area where rural tourism takes place is rural, but they have not defined the main body of rural tourism management. In the new era, the ultimate goal of vigorously promoting the implementation of the strategy of Rural Revitalization is to promote the development of farmers and realize the revitalization of rural areas. If the rural tourism is operated by the city and other outsiders, not only the local 
farmers can not be the beneficiaries of the development of rural tourism, but also result in the loss of its rurality, and the development of rural tourism and farmers will be hindered, due to foreign operators are not familiar with the rural human geography.

\subsection{Source-Protecting Quality of Planning and Developing}

The core resources of developing rural tourism in the new era are beautiful rural environment and excellent rural culture. If we do not pay attention to the protection of rural environment and the inheritance and development of excellent rural culture, the development of rural tourism will lose its strong foundation.

With the continuous improvement of people's material living standards, people put forward higher requirements for the quality of rural tourism development. The planning and development of rural tourism in the new era need not only beautiful rural environment and excellent rural culture as support, but also experiential, intelligent, informatization, modernization, toilet revolution, etc. into the planning and development of rural tourism to meet the personalized needs of tourists and the demand for quality. In the new era, rural tourism is no longer a synonym for simplicity, deficiency, dirty and backwardness.

\subsection{Rural Cultural Self-Confidence}

The broad masses of working people, especially the rural laborers, who are industrious and simple, are the main creators of China's 5000 years of history and culture. Under the guidance of Xi Jinping's important speech, "remembering homesickness", they will be able to set off a new upsurge in rural cultural construction. In the new era, it should vigorously explore and cultivate local talents in local culture, strive to implement the traditional craft revitalization plan, and accelerate the revival of traditional festival culture. The rural areas will form exquisite crafts, craft culture and folk culture, such as martial arts, opera, dragon dance, lion dance, and gongs and drums. In the end, a new rural culture situation with a taste of elegance and common taste will be formed.

\subsection{Coordination and Sharing}

The rural tourism in the new era is different from the simple agritainment. It is no longer a rural tourism with homogeneous competition, simple accommodation, poor diet and hygiene conditions, heavy environmental pollution, and inconsistent with ecological environment and regional industrial development.

In the new era, rural tourism is guided by the five development concepts. During the planning, it pays attention to unified planning. According to the characteristics of each region, it takes a differentiated development path to form a good situation of coordinated development of regional rural tourism. In the actual development of rural tourism, strengthen the protection of rural ecological environment, and the development of rural tourism drives a virtuous cycle of ecological environmental protection, which in turn forms a coordinated development of rural tourism and ecological environment. 


\section{Conclusion}

The concept and connotation of rural tourism are not invariable, but change with the development of the Times. The analysis of the connotation of the concept of rural tourism in the new era should be based on the characteristics of the times and deeply integrated with the new era. There is no end to the analysis of the concept and connotation of rural tourism. With the continuous progress and development of the times, the concept and connotation of rural tourism need more in-depth analysis and research. Based on the analysis of the connotation of rural tourism, this paper holds that the development of rural tourism in the new era should be in the following aspects. The development of rural tourism in the new era should be based on promoting the development of farmers, attracting farmers to participate in the development of rural tourism, constantly improving the ability of farmers to lead the development of rural tourism, and promoting the simultaneous improvement of farmers' quality and income; we should take the quality planning and development of conservation as the core, take the road of transformation and development of rural tourism, and realize the sustainable development of rural tourism. We should foster a strong atmosphere for the inheritance and development of excellent rural culture and gradually highlight the self-confidence of rural culture. We should aim at coordinating and sharing the advantages of different regions and sharing the fruits of regional development. We should guide all regions to form good relations that complement, promote and complement each other, so as to contribute to eliminating the main contradiction of unbalanced and inadequate development in our country.

\section{Funding}

1) Sichuan Provincial Social Sciences Research High-level Research Team: Sichuan Old Revolutionary Base Areas' Ecological Civilization Construction Research Team (Project No.: 18SCTD01).

2) Subsidized by Sichuan Tourism Development Research Center, Sichuan Key Research Base of Philosophy and Social Sciences (Project No. LYC18-47).

3) Subsidized by Sichuan Landscape and Recreation Research Center Project 2018 (JGYQ 2018036).

4) Subsidized by Philosophy and Social Science of Dazhou in 2019.

\section{Conflicts of Interest}

The author declares no conflicts of interest regarding the publication of this paper.

\section{References}

[1] Yang, X. (1992) Developing Rural Tourism Brooks No Delay. Tourism Tribune, 7, 38-41.

[2] Yao, S.Y. (1997) On Rural Tourism. Journal Beijing International Studies University, No. 3, 42-46. 
[3] Du, J. and Xiang, P. (1999) Thoughts on the Sustainable Development of Rural Tourism. Tourism Tribune, 1, 15-18.

[4] Xiao, Y.X., Ming, Q.Z. and Li, S.Z. (2001) On the Concept and Types of Rural Tourism. Tourism Science, No. 3, 8-10.

[5] He, J.M. and Li, L.H. (2002) Discussion on the Concept of Village Tourism. Journal of Southwest China Normal University, Humanities and Social Sciences Edition, No. 5, 125-128.

[6] Cha, F. (2004) Discussion on the Origin and Concept of Rural Tourism. Journal of Ankang Teachers College, No. 6, 29-32.

[7] Liu, H.Y. (2005) Thoughts on the Connotation of Rural Tourism. Journal of Xihua Normal University, Philosophy and Social Sciences, No. 2, 15-18.

[8] Li, K.Y. (2005) Rural Tourism Based on Rurality and Its Social Significance. Productivity Research, No. 6, 107-108, 169.

[9] Zhang, J. (2005) Analysis of Rural Tourism and Related Concepts. Land Greening, 11,15 .

[10] Liu, Y.J. and Wang, W.W. (2006) New Thoughts on the Concept System of Rural Tourism. Theoretical Circle, No. 4, 79-80.

[11] Lin, G. and Shi, P.J. (2006) Understanding of the Concept of Rural Tourism, Based on Quantitative Analysis of 20 Rural Tourism Concepts. Development Research, No. 6, 72-74.

[12] Tao, Y.X. (2009) The Problem of Space Equity in Tourism and the Three-Level Concept of Rural Tourism. Journal of Henan Normal University, Philosophy and Social Science Edition, 36, 120-123.

[13] Guo, L. and Zhang, J.E. (2010) Rethinking on the Concept of Rural Tourism and Its Connotation. Technology and Industry, 10, 58-61.

[14] Lu, X.L., Liu, W.W. and Wang, L.W. (2017) The Identification and Comparative Study of Rural Tourism Connotation Standards, Quantitative Analysis of 50 Rural Tourism Concepts in China and Foreign Countries. Resource Development and Market, 33, 759-763. 